\title{
Epidemiologisk forskning med utgangspunkt i Medisinsk fødselsregister
}

\author{
Anne Kjersti Daltveit og Lorentz M. Irgens \\ Avdeling for Medisinsk fødselsregister, Nasjonalt folkehelseinstitutt / Seksjon for epidemiologi og medisinsk \\ informatikk, Institutt for samfunnsmedisinske fag, Universitetet i Bergen \\ Korrespondanse: Anne Kjersti Daltveit, Medisinsk fødselsregister, Kalfarveien 31, 5018 Bergen \\ telefon: 55588529 telefax: 55586130 e-post: anne.daltveit@isf.uib.no
}

\begin{abstract}
SAMMENDRAG
Medisinsk fødselsregister (MFR) er basert på meldeplikt og har data om alle fødsler i Norge fra 1967. Lovhjemmel er MFR-forskriften av 2001 som også inkluderer melding av svangerskap etter in vitro fertilisering (IVF) og nemndbehandlede svangerskapsavbrudd på grunn av fostermisdannelser. Organisatoriske rammebetingelser, som innebærer samhandling mellom forvaltning og forskning, har ført til en omfattende utnyttelse av MFR i epidemiologisk forskning. I denne samhandlingen har Universitetet $\mathrm{i}$ Bergen spilt en sentral rolle gjennom hele registerets historie, og vil også fortsette å gjøre det i fremtiden. I dag er MFR integrert i Nasjonalt folkehelseinstitutt og har som en avdeling der et prioritert mål å yte tjenester til forskere med formål å øke bruken av MFR-data i epidemiologisk forskning.
\end{abstract}

Daltveit AK, Irgens LM. Epidemiological research based on the Medical Birth Registry of Norway. Nor J Epidemiol 2004; 14 (1): 47-52.

\section{ENGLISH SUMMARY}

The Medical Birth Registry of Norway (MBRN) is based on compulsory notification of all births in Norway from 1967 onwards. The legal authority is stated in the MBRN regulation from 2001 that also includes notification of pregnancies after in vitro fertilization and termination of pregnancy after 12 weeks of gestation due to birth defects. The organizational setting, in which close cooperation between management and research is essential, has been the basis for an extensive utilization of the MBRN data in epidemiological research. In this setting, the University of Bergen has played a pivotal role during the entire history of the registry, and will continue to do so in the future. Today, MBRN is integrated in The Norwegian Institute of Public Health, and has as a major goal to provide easy access to the information in the registry for epidemiologic research.

\section{INTRODUKSJON}

Medisinsk melding av fødsel ble innført i 1967. Bakgrunnen var Thalidomide-katastrofen på slutten av 1950- og begynnelsen av 1960-tallet, hvor rundt 10000 barn i Europa og USA ble født med manglende/misdannede lemmer fordi moren hadde benyttet legemiddelet Thalidomide i svangerskapet. En viktig hensikt var å oppdage bivirkninger av andre tilsvarende faktorer så snart som mulig for å begrense omfanget. Registerets formål, slik det fremgår av statutter fastsatt av Helsedirektoratet (nå Statens helsetilsyn) (1984) og forskrift for MFR (2001), er å levere informasjon som er nødvendig for å:

- Overvåke helseforholdene blant gravide og nyfødte, herunder medfødte misdannelser

- Overvåke helsetjenestetilbudet for gravide og nyfødte ved hjelp av utvalgte indikatorer
- Utvikle normer, standarder og retningslinjer for helsetjenesten på området

- Fremskaffe kunnskap om årsaksforhold som grunnlag for forebyggelse

Vi vil i denne artikkelen fokusere på det siste punktet, det vil si forskning og dens rammebetingelser med utgangspunkt i Medisinsk fødselsregister (MFR).

\section{ORGANISATORISKE RAMMEBETINGELSER}

Tor Bjerkedal var registerets første leder. Bjerkedal var da professor ved Det medisinske fakultet, Universitetet i Bergen (UIB). De første årgangene av fødselsmeldinger ble bearbeidet av Statistisk sentralbyrå, men det ble snart klart at anvendelsen av de registrerte opplysningene ville gå langt ut over Statistisk sentralbyrå sitt interesseområde. Det ble derfor etablert et samar- 
beide mellom Helsedirektoratet og UIB, Institutt for hygiene og sosialmedisin, om bearbeidelsen av fødselsmeldingene. På dette grunnlag ble MFR etablert $i$ 1970 ved UIB. Registerets organisatoriske tilknytning til den sentrale helseforvaltning har variert gjennom årene, men den sterke tilknytningen til UIB har stått ved lag. For mer utfyllende informasjon vises til en tidligere artikkel (1). Gjennom årene har både leder og annet personale ved MFR hatt en akademisk tilknytning til Det medisinske fakultet ved UIB. Denne nære tilknytningen mellom MFR og UIB er uten tvil en viktig grunn til den omfattende vitenskapelige utnyttelsen av materialet i MFR. Gjennom årene er mer enn 350 artikler med data fra MFR publisert, hovedsakelig i internasjonale tidsskrift. Særlig har det vært en omfattende vitenskapelig produksjon i løpet av det siste 10-året. Fra 2002 er MFR integrert som en avdeling i Nasjonalt folkehelseinstitutt (FHI) som ble opprettet samtidig. Dette gir MFR den viktige tilknytningen til den sentrale helseforvaltningen samtidig som det sikrer det økonomiske ressursgrunnlaget for en lovpålagt virksomhet. FHI og UIB har i 2004 inngått en avtale om opprettelse av to professorater øremerket for forskning ved MFR. Stillingene knyttes til Institutt for samfunnsmedisinske fag ved Det medisinske fakultet.

\section{REGISTEROPPLYSNINGER}

MFR er basert på meldeplikt og omfatter sivile opplysninger om mor, far og den nyfødte samt medisinske opplysninger om mors helse før og under svangerskapet, om fødselen, herunder komplikasjoner, og om den nyfødte, herunder medfødte misdannelser og andre medfødte tilstander. Alle levendefødte er fra og med 1967 registrert med oppfølgning frem til utskrivningen fra fødeavdelingen, likeledes dødfødte etter 16. svangerskapsuke. Gjennom rutinemessig kobling til Det sentrale folkeregister, hvor også barnets fødselsnummer innhentes, sikres en så å si komplett registrering av alle levendefødte og dødfødte over 28 svangerskapsuker. Fra Dødsårsaksregisteret innhentes rutinemessig informasjon om dødsfall i første leveår. Registreringsskjemaene fylles ut av lege og jordmor. Meldeskjema var på det nærmeste uendret i 30 år. Etter 1997 er det foretatt viktige endringer. I desember 1998 ble det tatt i bruk et nytt meldeskjema som også inneholder mer detaljerte opplysninger om bruk av medikamenter, herunder folsyre og multivitamintabletter, og om mors røkevaner og yrke. De to sistnevnte opplysningene forutsetter samtykke fra mor. Av andre nye opplysninger kan nevnes ultralydtermin og vekt av placenta, samt at det fra 1998 innhentes opplysninger fra barneavdelingene ved eventuell overflytting. Fra og med 1986 har MFR mottatt melding om graviditet etter in vitro fertilisering, og fra og med 1999 melding om nemndbehandlede aborter etter 12 . svangerskapsuke på indikasjon (melding på egne skjema). I 2001 fikk MFR sin egen forskrift der meldeplikten ble utvidet til å omfatte alle avsluttede graviditeter etter 12. svangerskapsuke, samtidig som utvidet oppfølgning ble hjemlet slik at MFR kan innhente opplysninger fra medisinske institusjoner i løpet av første leveår om alle tilstander som var til stede ved fødselen. Melderutinen for nemndbehandlede aborter ble hjemlet i forskriften sammen med en melderutine for graviditet utført etter in vitro fertilisering.

MFR er i likhet med andre epidemiologiske registre primært et utfallsregister, også kalt endepunktregister. Hovedutfallet er knyttet til den fødte eller moren, mens svangerskap og fødsel kan betraktes som eksposisjon eller utfall avhengig av problemstilling. At MFR er et utfallsregister vises tydelig ved at til tross for at Thalidomide-katastrofen var en viktig bakgrunn for opprettelsen av MFR, var det ikke lagt opp til en systematisk registrering av bruk av legemidler i svangerskapet på det meldeskjemaet som ble tatt i bruk i 1967 . For å kunne avdekke tilsvarende sammenhenger var det derfor forutsetningen at eksposisjonsdata skulle innhentes fra andre kilder. Dette er nødvendig fordi det vil være umulig å inkludere alle potensielle eksposisjonsdata $i$ et register. I det meldeskjemaet som har vært i bruk siden desember 1998, har man imidlertid inkludert noen viktige eksposisjonsdata. Dette gjelder bruk av legemidler under svangerskapet, røkning hos mor før og under svangerskapet, mors bruk av multivitaminer og folat før og under svangerskapet, samt mors yrke. Disse opplysningene vil ikke bare kunne brukes til å avdekke hovedeffekter av den aktuelle eksposisjonen, men vil også potensielt være viktige effektforvekslere og effektmodifikatorer i studier av andre årsaksfaktorer. Den første artikkelen som gjør bruk av de nye opplysningene om bruk av vitaminer er nå klar for publisering (2).

\section{VALIDITET}

De fleste undersøkelser av validiteten av analysevariablene i MFR er utført i tilknytning til spesifikke forskningsprosjekter. Svangerskapets varighet var før desember 1998 basert kun på opplysninger om siste menstruasjons første blødningsdag. En studie som tok for seg feilklassifisering av svangerskapets varighet viste et mønster som tydet på at en rekke fødsler er oppgitt med en svangerskapsvarighet som avviker med enheter på 4 uker fra den korrekte (3). Tolkningen av disse resultatene var at feilklassifisering av svangerskapets varighet kan være relatert til blødninger tidlig i svangerskapet, og funnene kan ha klinisk interesse.

I et prosjekt om fødsler blant kvinner med diagnosen rheumatoid artritt ble validiteten av denne diagnosen i MFR undersøkt ved å sammenligne med et kronisk rheumatologisk materiale (4). Av 169 tilfeller i dette materialet gjenfant man 149 (88\%) i MFR, hvorav 145 (97\%) med korrekt angitt type. Tilsvarende var diagnosen diabetes hos mor korrekt for $80 \%$ av diagnosene (upubliserte data). For kroniske tilstander 
hos mor kan man bruke informasjon om alle mors fødsler for å vurdere validiteten. Dette ble gjort i en studie av fødsler hos kvinner med myasthenia gravis (5). Ved å sammenholde alle mors fødsler fant man en høy grad av overensstemmelse når det gjaldt rapportering av denne tilstanden gjennom alle mors svangerskap. Generelt er det i slike studier viktig å unngå falske positive diagnoser. En høy andel falske positive vil bidra til å utvanne en eventuell effekt, mens en høy andel falske negative vil ha mindre betydning for resultatene. Å unngå både falske negative og positive diagnoser er særlig viktig når en ønsker å få korrekte tall for hyppighet. Andelen falske negative (mål for meldedekning eller ascertainment) av medfødte misdannelser ble undersøkt ved hjelp av et uavhengig meldesystem på 1980-tallet og varierte avhengig av hvilken tilstand som ble undersøkt (6).

\section{ANALYTISK DESIGN}

De fleste studier som benytter data fra MFR benytter kohortdesign der både eksposisjons- og utfalls-data hentes fra MFR. Alternativt kan eksposisjons- eller utfalls-data hentes fra andre kilder. Ofte benyttes alle uten den aktuelle eksposisjon som referansegruppe. Pasient kontroll studier har hittil vært utført i mindre grad. I pasient kontroll studier vil typisk det aktuelle utfallet finnes registrert i MFR, mens eksposisjonsdata må innhentes fra andre kilder. Dette kan bli mer aktuelt $\mathrm{i}$ fremtiden, fordi det vil være godt egnet dersom eksposisjonsdata hentes fra biologisk materiale. Trolig vil en rekke av delstudiene som tar utgangspunkt $\mathrm{i}$ kobling mellom MFR og data i Den norske mor og barn undersøkelsen, hvor det også samles inn biologisk materiale, egne seg for pasient kontroll studier. I studier hvor pasientdata innhentes fra sykehus eller annen klinisk virksomhet, kan MFR brukes som en kilde til innsamling av et kontrollmateriale. Dette gjøres $i$ en studie av leppe-ganespalte, hvor opplysninger om pasienter innhentes fra behandlende sykehus, mens kontrollene trekkes fra MFR (7).

I noen studier er det benyttet et økologisk design, det vil si at data om eksposisjon ikke finnes på individnivå, men bare på gruppenivå. Dette gjelder for eksempel en studie av fødselsutfall etter Tsjernobylulykken. Økologisk faktor her var radioaktivt nedfall som ble målt per måned for hver kommune i landet (8). Også en studie av betydningen av liggestilling for forekomsten av krybbedød benyttet et økologisk design (9). Spørreskjema ble sendt ut til en rekke kvinner som hadde fått barn i perioden 1967-1991, hvor de ble bedt om å rapportere hvilken stilling de hadde lagt barnet i. Økologisk faktor var andel barn som ble lagt i mageleie etter fødselsår og bostedsfylke. Studien viste en sammenheng mellom denne andelen og forekomsten av krybbedød, noe som indikerte at mageleie var en risikofaktor for krybbedød. Denne sammenhengen har siden slutten av 1980-tallet vært påvist gjennom en rekke studier i flere land. Andre eksempler der eksposisjonsdata har foreligget på gruppenivå og ikke på individnivå, er en studie av medfødte misdannelser og elektromagnetiske felt (10) og en studie av tidstrender i forekomsten av lav fødselsvekt (11).

\section{ANALYSE BASERT PÅ FAMILIESTRUKTURER}

Observasjonsenheten i MFR er den fødte (ikke fødsel), og de fleste studier tar utgangspunkt $\mathrm{i}$ den fødte som analyseenhet. Fordi MFR inneholder fødselsnummer både for den fødte, mor og far, kan data organiseres $\mathrm{i}$ ulike familiestrukturer. En rekke studier er basert på en struktur der de fødte er organisert som maternelle søskenflokker der alle barn av samme mor samles i en post og utgjør analyseenheten. I en slik analyse undersøker man eksempelvis hvorvidt mors tidligere svangerskap kan predikere utfall i påfølgende svangerskap. Denne analysestrategien ble benyttet første gang da gjentagelsesrisikoen for krybbedød i en søskenflokk ble undersøkt (12) og resultatene ble tillagt stor vekt internasjonalt; de innebar en nedjustering av tidligere estimater fra 10 til 5. Andre problemstillinger som har vært analysert i maternelle søskenflokker er perinatal dødelighet og fødselsvekt (13), dødsårsaker og dødfødsler (14) og ulike placentakomplikasjoner (15). Hovedfunnene i disse studiene har vært at noen, men ikke alle, uheldige svangerskapsutfall har en tendens til å gjenta seg hos samme kvinne. Selektiv fertilitet er et spesielt fenomen innen perinatal-epidemiologi som kan beskrives ved å studere søskenflokker (16). Selektiv fertilitet innebærer at en kvinne vil forsøke å erstatte et perinatalt tap, noe som fører til at kvinner med et tidligere perinatalt tap vil være overrepresentert blant kvinner med mange barn. I den grad perinatale tap er knyttet til en høy risiko for gjentagelse hos samme kvinne, vil noe av den økte risikoen for perinatalt tap ved høyt barnetall (høy paritet), kunne forklares med selektiv fertilitet. En analyse av maternelle søskenflokker vil kunne skille mellom effekten av selektiv fertilitet og den rene effekten av paritet på uheldige svangerskapsutfall.

I studier av søskenflokker kan en også inkludere opplysninger om far for å skille mellom helsøsken og paternelle og maternelle halvsøsken. Analyser av halvsøsken kan belyse betydningen av det paternelle eller føtale genetiske bidraget. En studie av preeklampsi var basert på en kobling mellom MFR og slektskapsdatabasen i Statistisk sentralbyrå, slik at en kunne identifisere fødende søstre, eventuelt halvsøstre, allerede fra 1967 og studere deres reproduksjon (17). I denne studien konkluderte en med at både maternelle og paternelle gener bidrar til preeklampsi. En annen studie av preeklampsi undersøkte effekten av å skifte partner. En analyse av maternelle søskenflokker i MFR viste at kvinner som skifter partner, har lengre avstand mellom svangerskapene, og at det var den lange avstanden og ikke selve partnerskiftet som kunne forklare den økte 
risikoen for preeklampsi som en ser for kvinner som skifter partner (18). Studien vakte oppsikt internasjonalt fordi resultatene sto i strid med en etablert hypotese om at risikoen for preeklampsi reduseres i senere svangerskap med samme partner. I studier av halvsøsken må en imidlertid nøye vurdere betydningen av livsstilsfaktorer som kan være relatert til det å skifte partner. I en studie hvor man fant at skifte av partner øte risikoen for spedbarnsdødelighet, for tidlig fødsel og lav fødselsvekt, kan det for eksempel tenkes at livsstilsfaktorer, og ikke genetiske mekanismer, i stor grad kan forklare funnene (19).

Ettersom registreret har vært i drift siden 1967, det vil si i mer enn 35 år, er det nå mulig å studere sammenhenger mellom fødselsutfall i generasjoner. Forekomsten av medfødte misdannelser i generasjoner har vært studert ved å se på reproduksjon hos kvinner og menn med medfødt misdannelse (20,21). Disse studiene konkluderte med at kvinner og menn som selv har en medfødt misdannelse hadde en høyere risiko for å få et barn med samme type misdannelse. Blant menn var det også en svak tendens til øket risiko for å få et barn med en annen type misdannelse. Et annet eksempel på en generasjonsstudie er studien av reproduksjon blant kvinner som var født av en kvinne med diabetes (22). Kvinner som var født av slike mødre (svangerskapsdiabetes unntatt) hadde tre ganger høyere risiko enn forventet for å få et dødfødt barn. Dette svarte til risikoen for dødfødsel hvis kvinnen selv hadde diabetes.

\section{OPPFØLGNINGSSTUDIER}

Med oppfølgningsstudier menes at en følger opp registrerte personer i MFR for å se på utfall senere i livet. En slik oppfølging kan gjelde foreldrene eller den fødte, og i slike studier vil data i MFR utgjøre eksposisjonen. Eksempler på oppfølgningsstudier av den fødte er analyser av sammenhenger mellom eksposisjon $i$ form av ulike svangerskapsutfall og astma i barnealder belyst med oppfølgningsdata fra Rikstrygdeverket (23), lærevansker i skolealder (med oppfølgningsdata fra spørreskjema, epikriser og Rikstrygdeverket) (24), og type 1 diabetes $\mathrm{i}$ barnealder (med oppfølgningsdata fra Norsk diabetesregister) (25). Et eksempel på en oppfølgingsstudie av foreldre er en studie av dødelighet og dødsårsaker for kvinner og menn som er registrert som foreldre $\mathrm{i}$ et preeklamptisk svangerskap med oppfølgningsdata fra Dødsårsaksregisteret (26). I denne studien fant en at kvinner som hadde gjennomgått et preeklamptisk svangerskap hadde øket dødelighet. Den økte dødeligheten var knyttet til kardiovaskulære årsaker (8 ganger høyere dødelighet), mens kreftdødeligheten var lavere enn i normalbefolkningen. Blant mennene var det ingen forskjell i dødelighet betinget av preeklampsi. Enda en oppfølgningsstudie er basert på en kobling mot sesjonsdata for å studere betydningen av fødselsparametre for helseutfall i voksen alder
(27). Kobling mellom MFR og Den norske mor og barn undersøkelsen vil på sikt gi muligheten til en rekke oppfølgningsstudier, både av foreldre og barn. Også kobling mot helseundersøkelsene vil gi mulighet for oppfølgningsstudier.

\section{FORSKNING BASERT PÅ KOBLEDE DATA}

For mange formål vil registreret inneholde tilstrekkelig informasjon, mens det i noen tilfeller vil være nødvendig å koble mot andre datakilder for å innhente mer opplysninger om eksposisjon, utfall eller potensielle effektforvekslere/effektmodifikatorer. Eksempler på koblede data er allerede nevnt for oppfølgningsstudier. Sosiodemografiske variabler er ofte ønsket av mange forskere som bruker data fra MFR. Sosiale forskjeller i helse er i seg selv et viktig tema, og en annen grunn til å inkludere sosiodemografiske variabler er at disse kan være viktige effektforvekslere. Det arbeides derfor med en avtale med Statistisk sentralbyrå om å opprette en permanent database av MFR data tilkoblet SSBs utdannelsesdata. Denne databasen vil også inneholde opplysninger om fødeland. Materialer basert på en kobling mellom MFR og SSBs data om utdannelse eller fødeland er benyttet i en studie av spedbarnsdødelighet og foreldres utdannelse (28) og i en studie av fødselsutfall blant pakistanske kvinner (29). Et eksempel på kobling mot helseundersøkelsene er en studie av fødsler og kvinnelig urininkontinens med data fra Helseundersøkelsen i Nord-Trøndelag HUNT 2 (30). Av andre koblinger kan nevnes kobling mot landbrukstellingene for å studere betydningen av eksposisjoner knyttet til landbruk for medfødte misdannelser (31), kobling mot folke- og boligtellingene for å studere betydningen av mors og fars yrke for medfødte misdannelser (32), og kobling mot Homocysteinundersøkelsen i Hordaland for å studere betydningen av mors homocysteinnivå for perinatale utfall (33). for oppfølgningsstudier.

\section{REGISTERFORSKNING VED UIB}

MFR utgjør tyngdepunktet i Locus for registerepidemiologi, som ble opprettet av Det medisinske fakultet ved UIB i 1998. Locus omfatter åtte helseregistre eller medisinske kvalitetsregistre: MFR, Nasjonalt register for leddproteser, Nasjonalt multippel sklerose register, Det norske nyrebiopsi-registeret, Nasjonalt porfyriregister, Norsk senter for kvalitetssikring av laboratorievirksomhet utenfor sykehus (NOKLUS), Helseundersøkelsen i Hordaland (HUSK) og Pasientregister for hjerte-, kar- og slagsykdom i Helseregion III (HKS-registeret). Formålet med opprettelsen var å prioritere registerbasert epidemiologisk forskning ved å gi forskningen større faglig tyngde og ved å gi stabilitet over tid, blant annet ved å stille driftsmidler til rådighet. Locus har som formål å initiere forskning basert på koblede datasett fra de ulike registrene, samt 
å fasilitere bruk av informasjonsteknologi i drift og forskning knyttet til registrene. I Locus-gruppen er det nå etablert flere samarbeidsprosjekter hvor studier basert på koblede data er i gang eller under planlegging.

\section{STØRRE PROSJEKTER OG SAMARBEIDSORGANER}

Den norske mor og barn undersøkelsen drives av MFR og FHI i Oslo. Studien inviterer gravide kvinner rundt uke 17 i forbindelse med den første ultralydundersøkelsen. Prosjektets biobank drives i Oslo, mens innhenting og behandling av spørreskjema som kvinnene fyller ut i løpet av graviditeten og etter at barnet er født utføres ved MFR. Studien startet i 1999 og det tas sikte på å samle inn data om 100000 fødsler. De første analysene vil bli utført i 2004 på et materiale som omfatter 20000 fødsler.

MFR deltar i og leverer data til to internasjonale nettverk som arbeider med overvåkning og forskning knyttet til medfødte misdannelser. International Clearinghouse for Birth Defects Monitoring Systems (ICBDMS) er en organisasjon som i samarbeide med verdens helseorganisasjon representerer 39 misdannelsesregistre verden over. EUROCAT er et europeisk nettverk av registre over medfødte misdannelser i 19 land, og dekker områder med $25 \%$ av alle fødsler i Europa, eller vel 1 million fødsler per år. MFR deltar også i Nordic Medical Birth Registries Association (NOMBIR) der viktige aktiviteter er etablering av en web-basert nordisk fødselsstatistikk, arbeid med obstetriske kvalitetsindikatorer og et forskningsprosjekt om obstetriske problemstillinger ved tvillingfødsel basert på nordiske data.

\section{OPPSUMMERING}

Registre med medisinske opplysninger om alle fødte finnes bare $\mathrm{i}$ de nordiske land. Disse registrene gir dermed unike muligheter for epidemiologiske studier av helseproblemer knyttet til svangerskap, fødsel og nyfødtperioden. MFR er det eldste av disse registrene og uten tvil det som har fătt den største anvendelsen i epidemiologisk forskning. Dette skyldes spesielle organisatoriske rammebetingelser ved at MFR har vært og blir drevet $\mathrm{i}$ form av en tett samhandling mellom forvaltning og forskning, i dag representert ved et samarbeid mellom Nasjonalt folkehelseinstitutt og Universitetet i Bergen. Dette har fasilitert et stort antall prosjekter også utenfor MFR, hvor MFR kun har vært dataleverandør. Lett adgang til data for eksterne brukere er et viktig mål for MFR. MFR forvalter data til belysning av problemområder som vil få stadig større samfunnsmessig betydning i årene som kommer og vil derfor fortsette å stå sentralt i norsk epidemiologisk forskning.

\section{REFERANSER}

1. Irgens LM. Medisinsk fødselsregister - et sentralt utgangspunkt for perinatalmedisinsk forskning. Tidsskr Nor Lageforen 2002; 122: 2546-9.

2. Vollset SE, Gjessing HK, Tandberg T, Rønning T, Irgens LM, Baste V, Nilsen RM, Daltveit AK. Twin pregnancies, folate and multivitamin use: The Medical Birth Registry of Norway. Second review.

3. Gjessing HK, Skjaerven R, Wilcox AJ. Errors in gestational age: evidence of bleeding early in pregnancy. Am J Public Health 1999; 89: 213-8.

4. Skomsvoll J, Ostensen M, Baste V, Irgens L. Validity of a rheumatic disease diagnosis in the Medical Birth Registry of Norway. Acta Obstet Gynecol Scand 2002; 81: 831-4.

5. Hoff JM, Daltveit AK, Gilhus NE. Myasthenia gravis: consequences for pregnancy, delivery, and the newborn. Neurology 2003; 61: 1362-6.

6. Lie RT, Heuch I, Irgens LM. Maximum likelihood estimation of the proportion of congenital malformations using double registration systems. Biometrics 1994; 50: 433-44.

7. Jugessur A, Lie RT, Wilcox AJ, Murray JC, Taylor JA, Saugstad OD, Vindenes HA, Abyholm FE. Cleft palate, transforming growth factor alpha gene variants, and maternal exposures: assessing gene-environment interactions in case-parent triads. Genet Epidemiol. 2003; 25: 367-74.

8. Lie RT, Irgens LM, Skjaerven R, Reitan JB, Strand P, Strand T. Birth defects in Norway by levels of external and food-based exposure to radiation from Chernobyl. Am J Epidemiol 1992; 136: 377-88.

9. Irgens LM, Markestad T, Baste V, Schreuder P, Skjaerven R, Oyen N. Sleeping position and sudden infant death syndrome in Norway 1967-91. Arch Dis Child 1995; 72: 478-82.

10. Blaasaas KG, Tynes T, Lie RT. Residence near power lines and the risk of birth defects. Epidemiology 2003; 14: $95-8$.

11. Daltveit AK, Vollset SE, Skjaerven R, Irgens LM. Impact of multiple births and elective deliveries on the trends in low birth weight in Norway, 1967-1995. Am J Epidemiol 1999; 149: 1128-33.

12. Irgens LM, Skjaerven R, Peterson DR. Prospective assessment of recurrence risk in sudden infant death syndrome siblings. J Pediatr 1984; 104: 349-51. 
13. Melve KK, Skjaerven R. Birthweight and perinatal mortality: paradoxes, social class, and sibling dependencies. Int J Epidemiol 2003; 32: 625-32.

14. Øyen N, Skjaerven R, Irgens LM. Population-based recurrence risk of sudden infant death syndrome compared with other infant and fetal deaths. Am J Epidemiol 1996; 144: 300-5.

15. Rasmussen S, Albrechtsen S, Dalaker K. Obstetric history and the risk of placenta previa. Acta Obstet Gynecol Scand 2000; 79: 502-7.

16. Skjaerven R, Wilcox AJ, Lie RT, Irgens LM. Selective fertility and the distortion of perinatal mortality. Am J Epidemiol 1988; 128: 1352-63.

17. Lie RT, Rasmussen S, Brunborg H, Gjessing HK, Lie-Nielsen E, Irgens LM. Fetal and maternal contributions to risk of pre-eclampsia: population based study. BMJ 1998; 316: 1343-7.

18. Skjaerven R, Wilcox AJ, Lie RT. The interval between pregnancies and the risk of preeclampsia. $N$ Engl $J$ Med 2002; 346: 33-8.

19. Vatten LJ, Skjaerven R. Change of partner between births and adverse pregnancy outcomes. Tidsskr Nor Laegeforen 2003; 123: 3546-8.

20. Skjaerven R, Wilcox AJ, Lie RT. A population-based study of survival and childbearing among female subjects with birth defects and the risk of recurrence in their children. $N$ Engl J Med 1999; 340: 1057-62.

21. Lie RT, Wilcox AJ, Skjaerven R. Survival and reproduction among males with birth defects and risk of recurrence in their children. JAMA 2001; 285: 755-60.

22. Egeland GM, Skjaerven R, Irgens LM. The reproductive health of daughters of pregestational diabetic women: Medical Birth Registry of Norway. Paediatr Perinat Epidemiol 2002; 16: 290-6.

23. Nafstad P, Samuelsen SO, Irgens LM, Bjerkedal T. Pregnancy complications and the risk of asthma among Norwegians born between 1967 and 1993. Eur J Epidemiol 2003; 18: 755-61.

24. Moster D, Lie RT, Markestad T. Joint association of Apgar scores and early neonatal symptoms with minor disabilities at school age. Arch Dis Child Fetal Neonatal Ed 2002; 86: F16-21.

25. Stene LC, Magnus P, Lie RT, Sovik O, Joner G. Birth weight and childhood onset type 1 diabetes: population based cohort study. BMJ 2001; 322: 889-92.

26. Irgens HU, Reisaeter L, Irgens LM, Lie RT. Long term mortality of mothers and fathers after pre-eclampsia: population based cohort study. BMJ 2001; 323: 1213-7.

27. Eide MG, Øyen N, Skjærven R, Nilsen ST, Bjerkedal T, Tell GS. Size at birth and gestational age as predictors for adult height and weight - a population based study of 348,706 male conscripts in Norway, 1967-99. Epidemiology (in press).

28. Arntzen A, Magnus P, Bakketeig LS. Different effects of maternal and paternal education on early mortality in Norway. Paediatr Perinat Epidemiol 1993; 7: 376-86.

29. Stoltenberg C, Magnus P, Lie RT, Daltveit AK, Irgens LM. Influence of consanguinity and maternal education on risk of stillbirth and infant death in Norway, 1967-1993. Am J Epidemiol 1998; 148: 452-9.

30. Rortveit G, Daltveit AK, Hannestad YS, Hunskaar S. Urinary incontinence after vaginal delivery or cesarean section. N Engl J Med 2003; 348: 900-7.

31. Kristensen P, Irgens LM, Andersen A, Bye AS, Sundheim L. Birth defects among offspring of Norwegian farmers, 1967-1991. Epidemiology 1997; 8: 537-44.

32. Irgens A, Kruger K, Skorve AH, Irgens LM. Birth defects and paternal occupational exposure. Hypotheses tested in a record linkage based dataset. Acta Obstet Gynecol Scand 2000; 79: 465-70.

33. Vollset SE, Refsum H, Irgens LM, Emblem BM, Tverdal A, Gjessing HK, Monsen AL, Ueland PM. Plasma total homocysteine, pregnancy complications, and adverse pregnancy outcomes: the Hordaland Homocysteine study. Am J Clin Nutr 2000; 71: 962-8. 